\title{
Arachnodactyly 患者の身體計測報告
}

\author{
增 谷乾
}

昭和 23 年 11 月、東京大學附屬病院冲中內科上り、入院中の Arachnodactyly 患者 の身體計测を任賴されたので、その結果を簡單に報告しておく。

患者㳉計测當時 30 年 5 月の男子で、杤木縣出身、職業は敎員であつた。

ての患者ひ體格は一見、左右不均齊で身長甚だ高く渡せており、四肢長く、屝平足で、

顐部は眉上隆起强く、顴弓は强く横に張つており、眨瞼は下垂している。頭部では後頭部

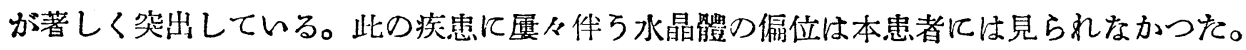

\begin{tabular}{|c|c|c|c|c|c|c|c|c|}
\hline 1 & 身長 & $175.6 \mathrm{~cm}$ & 23 & 指長 I & 6.4 & 45 & 上肢：身長 & 46.81 \\
\hline 2 & 胸骨上緣高 & 143.1 & 24 & $" \mathbb{I I}$ & 9.0 & 46 & 上膊：身長 & 21.53 \\
\hline 3 & 耻骨·縫際上緣高 & 87.4 & 25 & $=\mathbb{I}$ & 11.0 & 47 & 前膊：身長 & 14.52 \\
\hline 4 & 右膝關節高 & 46.9 & 26 & $" I V$ & 10.1 & 48 & 手長：身長 & 10.76 \\
\hline 5 & 右內踝端高 & 6.3 & 27 & $\Rightarrow \mathrm{V}$ & 7.8 & 49 & 手幅：身長 & 5.01 \\
\hline 6 & 右周峰高 & 147.8 & 28 & 跳長 I & 6.1 & 50 & 下肢：身長 & 52.79 \\
\hline 7 & 右肘關節高 & 110.0 & 29 & $\Rightarrow$ II & 5.6 & 51 & 大腿：身長 & 26.08 \\
\hline 8 & 右橈骨瞢高 & 84.5 & 30 & " III & 4.6 & 52 & 下腿：身長 & 23.12 \\
\hline 9 & 右中指端高 & 65.6 & 31 & $=\mathbb{N}$ & 4.2 & 53 & 足長：身長 & 15.66 \\
\hline 10 & 右腸骨·前上欶高 & 96.1 & 32 & $\Rightarrow V$ & 4.1 & 54 & 棘高 : 身長 & 54.73 \\
\hline 11 & 右乎湢 & 8.8 & 33 & 最大頭長 & $250 \mathrm{~mm}$ & 55 & 上肢長 : 下股長 & 88.67 \\
\hline 12 & 右足長 & 27.5 & 34 & 最大頭幅 & 148 & 56 & 前脯：上膊 & 67.46 \\
\hline 13 & 右足幅 & 9.7 & 35 & 前䪽最小幅 & 109 & 57 & 下腿 : 大腿 & 88.65 \\
\hline 14 & 胴前壁長 & 55.7 & 36 & 顴弓幅 & 144 & 58 & 乎幅：手長 & 46.56 \\
\hline 15 & 上肢長 & 82.2 & 37 & 下颚骨幅 & 103 & 59 & 足喀 : 足長 & 35.27 \\
\hline 16 & 上售長 & 37.8 & 38 & 形態學娩高 & 118 & 60 & 頭長幅示數 & 59.20 \\
\hline 17 & 前膊長 & 25.5 & 39 & 悬高 & 50 & 61 & 前頭：頭幅 & 73.65 \\
\hline 18 & 手長 & 18.9 & 40 & 鼻幅 & 40 & 62 & 孉傧：頭幅 & 97.30 \\
\hline 19 & 下肢辰 & 92.7 & 41 & 口裂幅 & 54 & 63 & 前頭：顴婳 & 75.69 \\
\hline 20 & 大腿長 & 45.8 & 42 & 外㫮幅 & 104 & 64 & 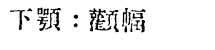 & 71.53 \\
\hline 21 & 下腿長 & 40.6 & 43 & 內㫮幅 & 35 & 65 & 形態胱示数 & 81.94 \\
\hline 22 & 乎背長 & 10.1 & 44 & 胴：身長 & 31.71 & 66 & 鼻指数 & 80.00 \\
\hline
\end{tabular}

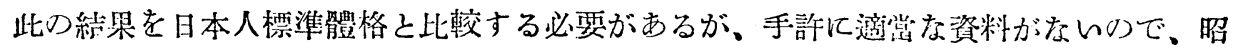
和 18 年 9 月。北村が金澤㗨大、附屬醫專。同藥專の學生 1046 名につんて行つた計测の 結果を基準とし、圖の如く關係偏差折線を以て示した。圖中計测部位を示す奥號は上表の 番號に相虽する。之より、身體各部位の計测值は主として $+\sigma$ と $+2 \sigma$ の附近にあるが 右內踝端高, 手幅等は著しく小で大思 $-2 \sigma,-\sigma$ 間に來る。足長は大きく $+4 \sigma$ 亿近く 

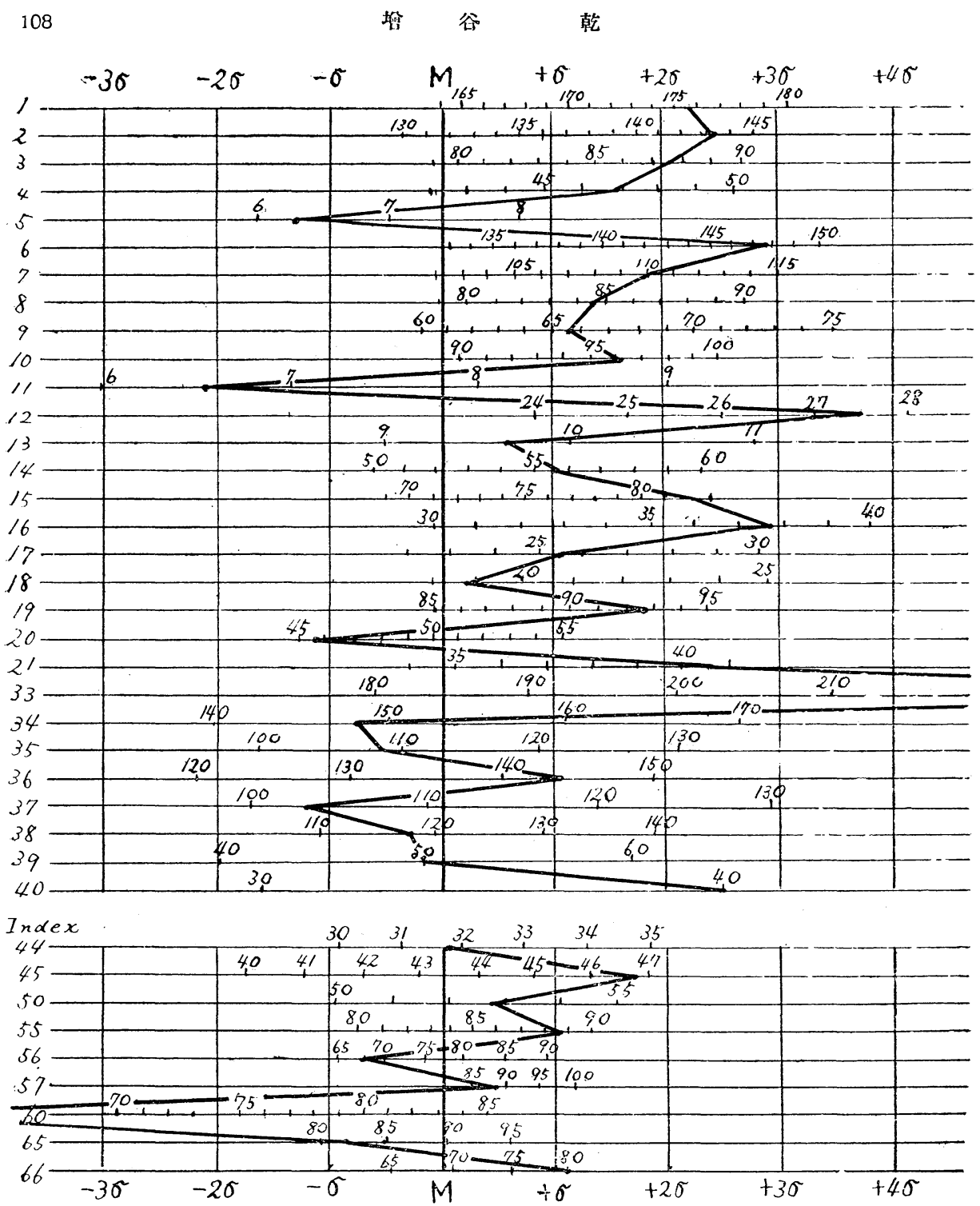

肩峰幅、上膊長が之に次いで $3 \sigma$ 亿近い。手長沈 $M$ 上 $+\sigma$ の間に亦る。大腿長が $-2 \sigma$ そ $-\sigma$ との閏に來たのは、計测法の相樭であるらしく、同じ方法を以てすれば平呁より 大であろうと思われる。身體が平均に比して大であるに反し、頭部は略了本均に近く、頭 長のみが非常に大きい $(\mathbf{M}=184)$ 。 又鼻幅も相當に大きいが、鼻幅等の計测に正確を期す るのは相賞に難しいから、あまり信用出來ない。示數では上肢：身長が $+2 \sigma$ 亿近く、又 頭長幅示數が瀶く程小さん。他は大凡 $\pm \sigma$ の間にある。 